\title{
STUDY OF SOME FACTORS AFFECTING DETERMINATION OF DYNAMIC ELASTIC CONSTANTS OF ROCKS
}

\section{ELSEMAN I. ABDEL-RASOUL,}

Associate Professor, Mining and Metallurgical Eng. Dept., Faculty of

Engineering, Assiut University, elseman1@yahoo.com.

(Received September 5, 2007 Accepted September 25, 2007)

\begin{abstract}
Measurements of the seismic wave velocities as well as the density of the rock material are necessary for calculating dynamic elastic constants. Correct determination of the dynamic elastic constants is the base for correct calculation of dynamic strains and stresses. These calculations use equations that haves been formulated according to some assumptions. This study investigates the effect of the assumptions of 1-D and 3-D wave propagation on the magnitudes of the estimated dynamic elastic constants. Also some relations between densities, seismic velocities, velocity ratio, Poisson's ratio, Young's modulus, and shear modulus will be developed. The study depicted a significant effect of the assumption of 1-D or 3-D wave propagation on the calculated magnitudes of the dynamic elastic constants and came up with some useful relationships between the above mentioned parameters.
\end{abstract}

KEYWORDS: Rock density, seismic wave velocities, dynamic elastic constants, dynamic stress and strain.

\section{INTRODUCTION}

The knowledge of mechanical and elastic properties is essential in any rock mechanics investigations related to mining, tunneling, drilling, blasting, cutting, or crushing. For example, estimation of the level of the dynamic strains and stresses induced by ground vibrations due to blasting operations in mines and quarries is of concern to the mining, civil, and geological engineers. The reason is that these strains and stresses may cause damage to mining structures such as high walls and mine openings or nearby structures such as dwelling buildings, bridges, dams, tunnels, pipelines, and underground power stations. To estimate these dynamic strains and stresses, bulk density, dynamic elastic constants and/or seismic wave velocities should be available. Measurements of the ground peak particle velocities at the locations of interest should be available as well. The elastic properties of rock materials are either evaluated from the conventional geotechnical methods or the in-situ geophysical measurements. Shallow geophysical techniques are considered as one of the accurate and cost effective methods used in engineering site characterization of the rock mass. They are an alternative means of the conventional geotechnical ones, which are sometimes tedious and very expensive. The rock mass quality depends mainly upon the material elastic constants, which include shear modulus (G), Poisson's ratio (v) and Young's modulus (E) [1-10]. 
Rock dynamic elastic constants are calculated from the longitudinal wave velocity $\left(C_{p}\right)$, shear wave velocity $\left(C_{s}\right)$ and density $(\rho)$. Generally, seismic wave velocities are higher for more dense and compact rocks than less dense and compact rocks; fine-grained than coarse-grained rocks; higher density than lower density rocks; lower porosity than higher porosity rocks; higher confining than lower confining pressures; lower temperature than higher temperature; and parallel to than perpendicular to bedding planes. The resonance and ultrasonic pulse methods are used to determine the elastic wave velocities in laboratory. The two methods do not give equivalent results even in nearly isotropic rocks. Although the discrepancy between the two methods probably is not of great significance in $\mathrm{E}$ and $\mathrm{G}$ determinations (about $6 \%$ ), it may be significant regarding $v$ determinations (could reach 24\%). Consequently, while either method might provide an adequate estimation of $\mathrm{E}$ and $\mathrm{G}, \mathrm{v}$ ratio determination by the resonance method is not recommended because of uncertainty with its determination. Seismic wave propagation method is used for field determinations of dynamic elastic constants. If the environmental conditions in the laboratory and in situ are the same, the results are comparable [11].

Usually $\mathrm{E}$ and $\mathrm{G}$ values obtained by dynamic methods are higher than those obtained by static techniques (both in the laboratory and in situ tests). The greater the degree of rock compactness, the more nearly dynamic and static elastic constants may agree. Static constants give rise to large scatter of results, but can be extended to the high strains $10^{-2}$ occurring in mining processes. In dynamic methods, low strains of $10^{-}$ 5 are involved with high rates of loading and scatter is comparatively small. Since dynamic methods usually involve low stresses, a comparison of static and dynamic values of $E$ is meaningful only if the values of the static $E$ are taken at comparable stress levels, i.e., using initial or zero stress tangent modulus. The static elastic modulus ranged from one-sixteenth to one-third of the seismic values [11].

In most cases, the values of the ratio of $\mathrm{C}_{\mathrm{s}} / \mathrm{C}_{\mathrm{p}}$ vary within a narrow range in crystalline and metamorphic rocks, between 1.7 and 1.9. The range of variation of this ratio is wider for sedimentary rocks (from 1.5 to 14), owing to the low shear strength of weak and porous rocks ( $v$ approaches 0.5 ). The value of this velocity ratio is very high for argillaceous rocks, and tends to infinity in friable rocks. It should be noted that seismic velocities does not depend on frequency in practice, so that it is possible to employ any frequency of vibrations in research [12].

Dowding mentioned that using bar velocity in calculating $\mathrm{E}$ is accurate enough for engineering applications [1]. Also, Coates [5] concluded that using bar velocity in calculating $\mathrm{E}$ or vice versa, would produce an answer about $5 \%$ higher than using longitudinal wave velocity. Abdel-Rasoul and Omran [7] observed that E is higher in case of using bar velocity than in case of using longitudinal wave velocity. Also, they observed that the percentage of E-increase increases with increasing Poisson's ratio.

\section{AIM OF THE RESEARCH}

Calculations of the dynamic strains and stresses are based on predetermined dynamic elastic constants ( $v, E$ and G). Determination of these dynamic elastic constants depends on assumptions, measurements (rock density and seismic wave velocities) and calculation procedures. This paper investigates the effect of the assumption of 1- 
D or 3-D wave propagation on the magnitudes of the dynamic elastic constants. Also, interrelations between rock densities, $\mathrm{C}_{\mathrm{p}}, \mathrm{C}_{\mathrm{s}}, \mathrm{C}_{\mathrm{s}} / \mathrm{C}_{\mathrm{p}}, \mathrm{v}, \mathrm{E}, \mathrm{G}$, and v-factor as well as the calculation procedures would be investigated.

\section{RELATIONS BETWEEN $C_{p}, C_{s}$, DYNAMIC ELASTIC CONSTANTS, STRAINS AND STRESSES}

In derivation of the following relations, it is assumed that the rock material is homogeneous, isotropic, and perfectly elastic.

\section{Relations between $C_{p}, C_{s}$ and Dynamic Elastic Constants [1, 5, 7-12]:}

Bar velocities (1-D) are given by:

$$
\mathrm{C}_{\mathrm{p}}=(\mathrm{E} / \rho)^{1 / 2}
$$

From which, Young's Modulus is:

$$
\mathrm{E}=\rho \mathrm{C}_{\mathrm{p}}^{2}
$$

The longitudinal wave propagation velocities (3-D) are related to the elastic constants by the following equation:

$$
\left(C_{p}\right)^{2}=(1-v) E /[(1+v)(1-2 v) \rho]
$$

From which, $\mathrm{E}$ is:

$$
\mathrm{E}=\rho\left(\mathrm{C}_{\mathrm{p}}\right)^{2}[(1+v)(1-2 v) /[(1-v)]
$$

Shear wave velocity is given by the equation:

$$
\mathrm{C}_{\mathrm{s}}=(\mathrm{G} / \rho)^{1 / 2}
$$

From which, shear modulus (3-D) is:

$$
\mathrm{G}=\rho \mathrm{C}_{\mathrm{s}}^{2}
$$

Also, we have the following expression for shear wave velocity:

$$
\left(C_{s}\right)^{2}=E /[2(1+v) \rho]
$$

With some manipulation between equation (3) and equation (7), we can find the following equation for calculating $v$ :

$$
v=\left[1-2\left(\mathrm{C}_{\mathrm{s}} / \mathrm{C}_{\mathrm{p}}\right)^{2}\right] /\left[2-2\left(\mathrm{C}_{\mathrm{s}} / \mathrm{C}_{\mathrm{p}}\right)^{2}\right]
$$

And

$$
\mathrm{C}_{\mathrm{s}}=[(1-v) /(1 / 2-v)]^{1 / 2}
$$

In case of $v=0.25$, the $C_{p} / C_{s}$ ratio is equal to 1.7. Also $E$ and $G$ are related by the following equation:

$$
\mathrm{G}=\mathrm{E} / 2(1+v)
$$

\section{Dynamic Strains and Stresses [1, 5]:}

Young's modulus (in uniaxial compression or tensile tests) is defined as:

$$
\mathrm{E}=\sigma / \varepsilon
$$

i.e. $\quad \sigma=\mathrm{E} \varepsilon$ 
And the normal (longitudinal) strain is defined as:

$$
\varepsilon=\stackrel{\circ}{\mathrm{p}}_{\mathrm{p}} / \mathrm{C}_{\mathrm{p}}
$$

Using equations (2), (12), and (13), normal stress, $\sigma$ can be expressed as:

$$
\sigma=\rho \mathrm{C}_{\mathrm{p}} \stackrel{\circ}{\mathrm{p}}_{\mathrm{p}}
$$

Also, shear modulus, $\mathrm{G}$, is defined as:

$$
\mathrm{G}=\tau / \gamma
$$

i.e. $\quad \tau=\mathrm{G} \gamma$

And shear strain is defined as:

$$
\gamma=\stackrel{\circ}{\mathrm{u}}_{\mathrm{s}} /-\mathrm{C}_{\mathrm{s}}
$$

Using equations (6), (16), and (17), shear stress, $\tau$ can be expressed as:

$$
\tau=\rho \mathrm{C}_{\mathrm{s}} \stackrel{\circ}{\mathrm{u}}_{\mathrm{s}}
$$

Where:

$$
\begin{aligned}
& \varepsilon=\text { normal strain } \\
& \sigma=\text { normal stress } \\
& \stackrel{\circ}{\mathrm{p}}_{\mathrm{p}}=\text { longitudinal particle velocity. } \\
& \stackrel{\circ}{\mathrm{s}}_{\mathrm{s}}=\text { transverse ( } h \text { ear) particle velocity } \\
& \gamma=\text { shear strain } \\
& \tau=\text { shear stress }
\end{aligned}
$$

\section{CALCULATION OF $\mathbf{C}_{\mathrm{s}} / \mathbf{C}_{\mathrm{p}}, \boldsymbol{v}, \boldsymbol{v}$-FACTOR, E AND G}

We have collected rock density, $\mathrm{C}_{\mathrm{P}}$ and $\mathrm{C}_{\mathrm{S}}$ for rocks from different sources. Some data contain field measurements of $C_{P}$ and $C_{S}[4,6,7,14]$ while other data contain laboratory measurements of $\mathrm{C}_{\mathrm{P}}$ and $\mathrm{C}_{\mathrm{S}}$ [11]. Another group of data is provided as an average and it could be a mix of field and laboratory measurements [13]. We have calculated $\mathrm{C}_{S} / \mathrm{C}_{\mathrm{P}}$ and $v$ (using equation (8)) for these data. Summary of these calculations is provided in Table1. The last term in equation (4) has been called Poisson's Ratio Factor and is defined as:

$$
v \text {-factor, } F=[(1+v)(1-2 v) /[(1-v)]
$$

Its magnitude has been calculated for all rocks and it is provided in Table 2.

E has been calculated using two methods. In the first method, E has been calculated using bar velocity, equation (2) based on the assumption of 1-D wave propagation $\left(\mathrm{E}_{1-\mathrm{D}}\right)$. In the second method, $\mathrm{E}$ has been calculated using longitudinal wave velocity as defined in equation (4) and based on the assumption of 3-D wave propagation $\left(\mathrm{E}_{3-\mathrm{D}}\right)$. It is observed that $\mathrm{E}_{1-\mathrm{D}}$ is greater than $\mathrm{E}_{3-\mathrm{D}}$. The percentage of increase has been calculated as:

$$
\text { E-Increase } \%=\left[\mathrm{E}_{1-\mathrm{D}}-\mathrm{E}_{3-\mathrm{D}}\right] \times 100 / \mathrm{E}_{3-\mathrm{D}}
$$

Calculations of $\mathrm{E}$ are summarized in Table 2.

$\mathrm{G}$ has been calculated using three methods. In the first method, we used $\mathrm{E}_{1-\mathrm{D}}$ in equation (10) to calculate $\mathrm{G}$ (being based on 1-D wave propagation, we called it $\mathrm{G}_{1-\mathrm{D}}$ ). In the second method, we used $\mathrm{E}_{3-\mathrm{D}}$ in equation (10) to calculate G. Being calculated on the 3-D wave propagation assumption; we called it $\mathrm{G}_{3-\mathrm{D}}$. In the third method, we 
used $\mathrm{C}_{\mathrm{s}}$ in equation (6) to calculate $\mathrm{G}$ (called $\mathrm{G}_{3-\mathrm{D}(\mathrm{cs})}$ or $\mathrm{G}_{\mathrm{cs}}$ ). Results of $\mathrm{G}$ calculations are provided in Table 2. In the table, it can be seen that the second and third methods produce the same G magnitudes. That is because the two methods are based on the 3-D wave propagation assumption. Also, it can be seen that $G_{1-D}$ is greater than $G_{3-D}$. That is because we used $E_{1-D}$ in equation (10) which is based on the assumption of 1-D wave propagation. The percentage of $\mathrm{G}$ increase is calculated as:

$$
\text { G-Increase } \%=\left[G_{1-D}-G_{3-D}\right] \times 100 / G_{3-D}
$$

Results of these calculations are provided in Table 2. 
Table 1: Summary of rock density, $C_{P}, C_{S}$, and calculations of $C_{S} / C_{P}$ and $v$.

\begin{tabular}{|c|c|c|c|c|c|c|}
\hline$\frac{\dot{0}}{\dot{z}}$ & Rock Type & 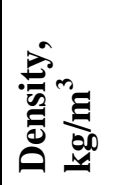 & 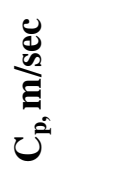 & 总 & $\underbrace{v^{n}}_{U^{n}}$ & 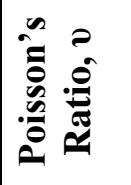 \\
\hline \multicolumn{7}{|c|}{ Abdel-Rasoul and Omran [7] } \\
\hline 1 & Limestone, layer 1 & 2000 & 1661 & 1038 & 0.6249 & 0.180 \\
\hline 2 & Limestone, layer 1 & 2000 & 1612 & 1003 & 0.6222 & 0.178 \\
\hline 3 & Limestone, layer 2 & 2200 & 2838 & 1715 & 0.6043 & 0.212 \\
\hline 4 & Limestone, layer 2 & 2200 & 2480 & 1649 & 0.6649 & 0.104 \\
\hline 5 & Limestone, layer 3 & 2200 & 4604 & 3081 & 0.6692 & 0.094 \\
\hline 6 & Limestone, layer 3 & 2200 & 4380 & 2933 & 0.6696 & 0.0935 \\
\hline \multicolumn{7}{|c|}{ Tealeb et al [6] } \\
\hline 7 & Weathered Limestone & 2400 & 385 & 226 & 0.5870 & 0.237 \\
\hline 8 & Foundation Limestone & 2400 & 952 & 560 & 0.5882 & 0.235 \\
\hline \multicolumn{7}{|c|}{ Burgher [4] } \\
\hline 9 & Montana mine rocks & 2610 & 2487 & 1463 & 0.5883 & 0.235 \\
\hline \multicolumn{7}{|c|}{ Kabongo [14] } \\
\hline 10 & Coal & 1475 & 3800 & 2400 & 0.6316 & 0.168 \\
\hline \multicolumn{7}{|c|}{ Atlas Powder [13] } \\
\hline 11 & Granite & 2670 & 5029 & 2743 & 0.5454 & 0.288 \\
\hline 12 & Gabbro & 2980 & 6553 & 3444 & 0.5256 & 0.309 \\
\hline 13 & Basalt & 3000 & 5608 & 3048 & 0.5435 & 0.290 \\
\hline 14 & Dunite & 3280 & 7985 & 4084 & 0.5115 & 0.323 \\
\hline 15 & Sandstone & 2450 & 3353 & 1981 & 0.5908 & 0.232 \\
\hline 16 & Limestone & 2650 & 4572 & 2972 & 0.6500 & 0.134 \\
\hline 17 & Shale & 2350 & 2895 & 1676 & 0.5790 & 0.248 \\
\hline 18 & Slate & 2800 & 3962 & 2865 & 0.7231 & 0.047 \\
\hline 19 & Marble & 2750 & 5791 & 3505 & 0.6052 & 0.211 \\
\hline 20 & Schist & 2800 & 4541 & 2895 & 0.6375 & 0.158 \\
\hline
\end{tabular}


Table 1: ...continued

\begin{tabular}{|c|c|c|c|c|c|c|}
\hline$\frac{\dot{0}}{\dot{Z}}$ & Rock Type & 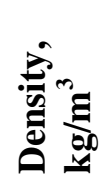 & 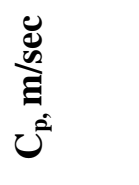 & 总 & $\underbrace{\sum^{n}}_{U^{n}}$ & 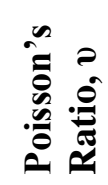 \\
\hline \multicolumn{7}{|c|}{ Lama and Vutukuri [11] } \\
\hline 21 & Hornblende Schist & 2990 & 6090 & 3720 & 0.6108 & 0.202 \\
\hline 22 & Granulite & 3053 & 6310 & 3390 & 0.5372 & 0.297 \\
\hline 23 & Hornblende Schist & 3052 & 6340 & 3980 & 0.6378 & 0.186 \\
\hline 24 & Hornblende Schist & 2737 & 6300 & 3920 & 0.6222 & 0.184 \\
\hline 25 & Hornblende Schist & 3011 & 6690 & 3670 & 0.5486 & 0.285 \\
\hline 26 & Hornblende Schist & 2961 & 6730 & 4000 & 0.5944 & 0.227 \\
\hline 27 & Dolerite & 3106 & 5220 & 3340 & 0.6398 & 0.153 \\
\hline 28 & Uralite diabase & 3162 & 6130 & 3130 & 0.5106 & 0.324 \\
\hline 29 & Hornblendite & 3247 & 5630 & 3630 & 0.6448 & 0.144 \\
\hline 30 & Dolerite & 3000 & 6370 & 3440 & 0.5400 & 0.294 \\
\hline 31 & Hornblende granulite & 3042 & 6700 & 3590 & 0.5358 & 0.299 \\
\hline 32 & Hornblende schist & 3198 & 5840 & 3530 & 0.6045 & 0.212 \\
\hline 33 & Hornblende schist & 3031 & 6360 & 3750 & 0.5896 & 0.225 \\
\hline 34 & Hornblendite & 3472 & 6390 & 3290 & 0.5149 & 0.320 \\
\hline 35 & Dolerite & 3136 & 6480 & 3730 & 0.5756 & 0.252 \\
\hline 36 & Vein quartz & 2796 & 5210 & 2840 & 0.5451 & 0.289 \\
\hline 37 & Hornblende granulite & 3084 & 6110 & 3710 & 0.6072 & 0.208 \\
\hline 38 & Hornblende schist & 3011 & 5750 & 3700 & 0.6435 & 0.154 \\
\hline 39 & Uralite basalt & 3062 & 6580 & 3660 & 0.5562 & 0.276 \\
\hline 40 & Uralite basalt & 2672 & 5010 & 3160 & 0.6307 & 0.170 \\
\hline 41 & Dolerite & 3111 & 5590 & 3300 & 0.5903 & 0.233 \\
\hline 42 & Granulite & 3106 & 6150 & 3380 & 0.5496 & 0.284 \\
\hline 43 & Granulite & 3356 & 5420 & 3150 & 0.5812 & 0.245 \\
\hline 44 & Uralite diabase & 3000 & 6650 & 3710 & 0.5579 & 0.274 \\
\hline 45 & Dolerite & 3011 & 5440 & 3500 & 0.6434 & 0.147 \\
\hline 46 & Uralite diabase & 3057 & 6100 & 3840 & 0.6295 & 0.172 \\
\hline 47 & Tremolite schist & 3011 & 6320 & 3460 & 0.5475 & 0.286 \\
\hline
\end{tabular}

ANALYSES AND DISCUSSIONS OF RESULTS

Fig. 1 illustrates the relation between $C_{P}, C_{S}$, and density. The relations have very good correlation coefficients $\left(\mathrm{R}=0.78\right.$ for $\mathrm{C}_{\mathrm{P}}$ and $\mathrm{R}=0.73$ for $\left.\mathrm{C}_{S}\right)$. These high correlation coefficients give us confidence in our data base and recommend the use of the relations to predict appreciable values for $C_{P}$ and $C_{S}$. The relations show the increase of $C_{P}$ and $\mathrm{C}_{\mathrm{S}}$ with increasing density. At densities greater than about $2000 \mathrm{~kg} / \mathrm{m}^{3}$, the rate of increase of $\mathrm{C}_{\mathrm{s}}$ decreases compared to the rate of increase of $\mathrm{C}_{\mathrm{p}}$. 
Table 2: Summary of the calculations of $\mathrm{v}$-factor; dynamic $\mathrm{E}$ and $\mathrm{G}$ by different methods.

\begin{tabular}{|c|c|c|c|c|c|c|c|c|}
\hline \multirow[b]{2}{*}{$\frac{\dot{0}}{2}$} & \multirow[b]{2}{*}{ 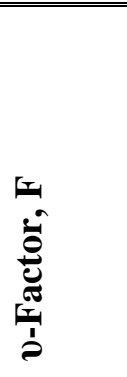 } & \multicolumn{3}{|c|}{$\begin{array}{c}\text { Young's Modulus, E, } 10^{4} \\
\text { kg/cm }\end{array}$} & \multicolumn{4}{|c|}{ Rigidity Modulus, G, $10^{4} \mathrm{~kg} / \mathrm{cm}^{2}$} \\
\hline & & 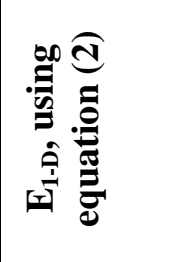 & 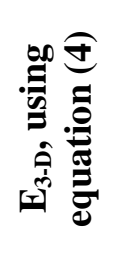 & 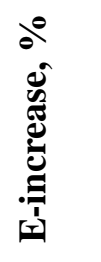 & 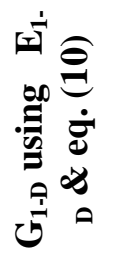 & 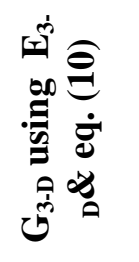 & 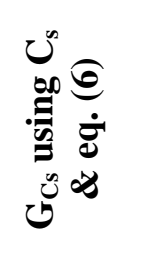 & 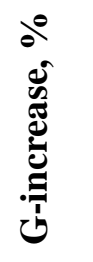 \\
\hline \multicolumn{9}{|c|}{ Abdel-Rasoul and Omran [7] } \\
\hline 1 & 0.921 & 5.625 & 5.180 & 8.58 & 2.383 & 2.195 & 2.197 & 8.5 \\
\hline 2 & 0.9229 & 5.298 & 4.889 & 8.35 & 2.249 & 2.075 & 2.076 & 8.3 \\
\hline 3 & 0.8859 & 18.063 & 16.002 & 12.9 & 7.452 & 6.602 & 6.596 & 13.0 \\
\hline 4 & 0.9759 & 13.793 & 13.46 & 2.47 & 6.247 & 6.096 & 6.098 & 6.1 \\
\hline 5 & 0.9805 & 47.536 & 46.613 & 1.98 & 21.726 & 21.304 & 21.288 & 2.1 \\
\hline 6 & 0.9807 & 43.023 & 42.193 & 1.97 & 19.672 & 19.293 & 19.292 & 2.0 \\
\hline \multicolumn{9}{|c|}{ Tealeb et al [6] } \\
\hline 7 & 0.8528 & 0.363 & 0.309 & 17.3 & 0.1466 & 0.125 & 0.125 & 17.3 \\
\hline 8 & 0.8556 & 2.217 & 1.897 & 16.9 & 0.8977 & 0.768 & 0.767 & 17.0 \\
\hline \multicolumn{9}{|c|}{ Burgher [4] } \\
\hline$\overline{99}$ & 0.8556 & 16.451 & 14.076 & 16.9 & 6.6602 & 5.699 & 5.696 & 16.9 \\
\hline \multicolumn{9}{|c|}{ Kabongo [14] } \\
\hline 10 & 0.9322 & 21.712 & 20.239 & 7.28 & 9.2943 & 8.664 & 8.661 & 7.32 \\
\hline \multicolumn{9}{|c|}{ Atlas Powder [13] } \\
\hline 11 & 0.7670 & 68.834 & 52.796 & 30.4 & 26.721 & 20.495 & 20.478 & 30.5 \\
\hline 12 & 0.7236 & 130.445 & 94.396 & 38.2 & 49.826 & 36.056 & 36.031 & 38.3 \\
\hline 13 & 0.7631 & 96.176 & 73.392 & 31.0 & 37.278 & 28.447 & 28.411 & 31.2 \\
\hline 14 & 0.6918 & 213.184 & 147.48 & 44.6 & 80.568 & 55.736 & 55.767 & 44.5 \\
\hline 15 & 0.8598 & 28.078 & 24.142 & 16.3 & 11.395 & 9.798 & 9.801 & 16.3 \\
\hline 16 & 0.9585 & 56.466 & 54.125 & 4.3 & 24.897 & 23.865 & 23.860 & 4.4 \\
\hline 17 & 0.8364 & 20.077 & 16.793 & 19.6 & 8.044 & 6.728 & 6.729 & 19.5 \\
\hline 18 & 0.9954 & 44.804 & 44.598 & 0.00 & 21.396 & 21.298 & 23.428 & 0.0 \\
\hline 19 & 0.8871 & 94.009 & 83.400 & 12.7 & 34.438 & 34.434 & 34.438 & 12.7 \\
\hline 20 & 0.9407 & 58.856 & 55.366 & 6.3 & 23.921 & 23.906 & 23.921 & 6.2 \\
\hline
\end{tabular}

Fig. 2 and Fig. 3 present the relations between $E_{1-D}, E_{3-D} ; G_{1-D}, G_{3-D}$, and Poisson's ratio. Despite the low correlation coefficients $(\mathrm{R}=0.54,0.34,0.46$, and 0.26 respectively), the figures do show the increase of $E$ and $G$ with increasing Poisson's 
ratio. Also, the figures show that the difference between 1-D and 3-D magnitudes increases with increasing Poisson's ratio.

Table 2: ....continued.

\begin{tabular}{|c|c|c|c|c|c|c|c|c|}
\hline \multirow[b]{2}{*}{$\frac{\dot{\dot{z}}}{\dot{\sigma}}$} & \multirow[b]{2}{*}{ 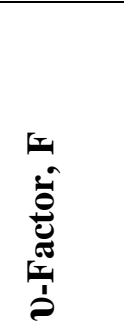 } & \multicolumn{3}{|c|}{$\begin{array}{l}\text { Young's Modulus, E, } 10^{4} \\
\mathrm{~kg} / \mathrm{cm}^{2}\end{array}$} & \multicolumn{4}{|c|}{ Rigidity Modulus, G, $10^{4} \mathrm{~kg} / \mathrm{cm}^{2}$} \\
\hline & & 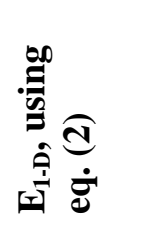 & 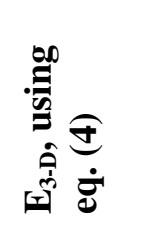 & 氧 & 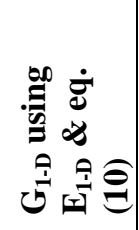 & 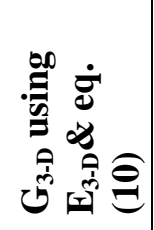 & 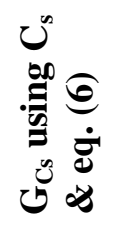 & 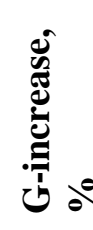 \\
\hline \multicolumn{9}{|c|}{ Lama and Vutukuri [11] } \\
\hline 21 & 0.8977 & 113.041 & 101.481 & 11.4 & 47.022 & 42.213 & (42.178 & 11.5 \\
\hline 22 & 0.7490 & 123.913 & 92.811 & 33.5 & 47.769 & 35.779 & 35.765 & 33.6 \\
\hline 23 & 0.9150 & 125.053 & 114.423 & 9.3 & 52.810 & 48.321 & 49.281 & 7.2 \\
\hline 24 & 0.9170 & 110.736 & 101.547 & 9.1 & 46.763 & 42.883 & 42.872 & 9.1 \\
\hline 25 & 0.7728 & 137.371 & \begin{tabular}{|l|l}
106.160 \\
\end{tabular} & 29.4 & 53.452 & 41.307 & 41.340 & 29.3 \\
\hline 26 & 0.8667 & 136.710 & 118.483 & 15.4 & 55.709 & 48.282 & 48.294 & 15.4 \\
\hline 27 & 0.9447 & 86.273 & 81.504 & 5.9 & 37.412 & 35.344 & 35.320 & 5.9 \\
\hline 28 & 0.6894 & 121.120 & 83.502 & 45.1 & 45.740 & 31.534 & 31.578 & 44.9 \\
\hline 29 & 0.9516 & 104.913 & 99.830 & 5.1 & 45.854 & 43.632 & 43.614 & 5.1 \\
\hline 30 & 0.7551 & 124.088 & 93.704 & 32.4 & 47.948 & 36.207 & 36.188 & 32.5 \\
\hline 31 & 0.7449 & 139.200 & 103.695 & 34.2 & \begin{tabular}{|l|}
53.578 \\
\end{tabular} & 39.913 & 39.965 & 34.1 \\
\hline 32 & 0.8859 & 111.182 & 98.500 & 12.9 & 45.867 & 40.635 & 40.622 & 12.9 \\
\hline 33 & 0.8694 & 124.977 & 108.650 & 15.0 & 51.011 & 44.347 & 43.449 & 17.4 \\
\hline 34 & 0.6988 & 144.515 & \begin{tabular}{|l|}
100.990 \\
\end{tabular} & 43.1 & 54.740 & 38.254 & 38.309 & 42.9 \\
\hline 35 & 0.8302 & 134.232 & 111.440 & 20.5 & 53.607 & 44.505 & 44.476 & 20.5 \\
\hline 36 & 0.7651 & 77.365 & 59.189 & 30.7 & 30.010 & 22.959 & 22.988 & 30.5 \\
\hline 37 & 0.8907 & 117.362 & 104.540 & 12.3 & 48.577 & 43.270 & 43.271 & 12.3 \\
\hline 38 & 0.9439 & 101.479 & 95.7897 & 5.9 & 43.969 & 41.503 & 42.019 & 4.6 \\
\hline 39 & 0.7859 & 135.141 & 106.202 & 27.3 & 52.955 & 41.615 & 41.812 & 26.7 \\
\hline 40 & 0.9304 & 68.366 & 63.606 & 7.5 & 29.216 & 27.182 & 27.198 & 7.4 \\
\hline 41 & 0.8584 & 99.096 & 85.068 & 16.5 & 40.185 & 34.496 & 34.535 & 16.4 \\
\hline 42 & 0.7747 & 119.752 & 92.772 & 29.1 & 46.632 & 36.126 & 36.171 & 28.9 \\
\hline 43 & 0.841 & 100.497 & 84.517 & 18.9 & 40.360 & 33.943 & 33.945 & 18.9 \\
\hline 44 & 0.7932 & 135.237 & 107.267 & 26.1 & 53.076 & 42.099 & 42.092 & 26.1 \\
\hline 45 & 0.9493 & 90.832 & 86.230 & 5.3 & 39.596 & 37.589 & 37.599 & 5.3 \\
\hline 46 & 0.9285 & 115.954 & 107.668 & 7.7 & 49.469 & 45.934 & 45.950 & 7.7 \\
\hline 47 & 0.8645 & 122.596 & 105.984 & 15.7 & 47.666 & 41.207 & 36.745 & 29.7 \\
\hline
\end{tabular}




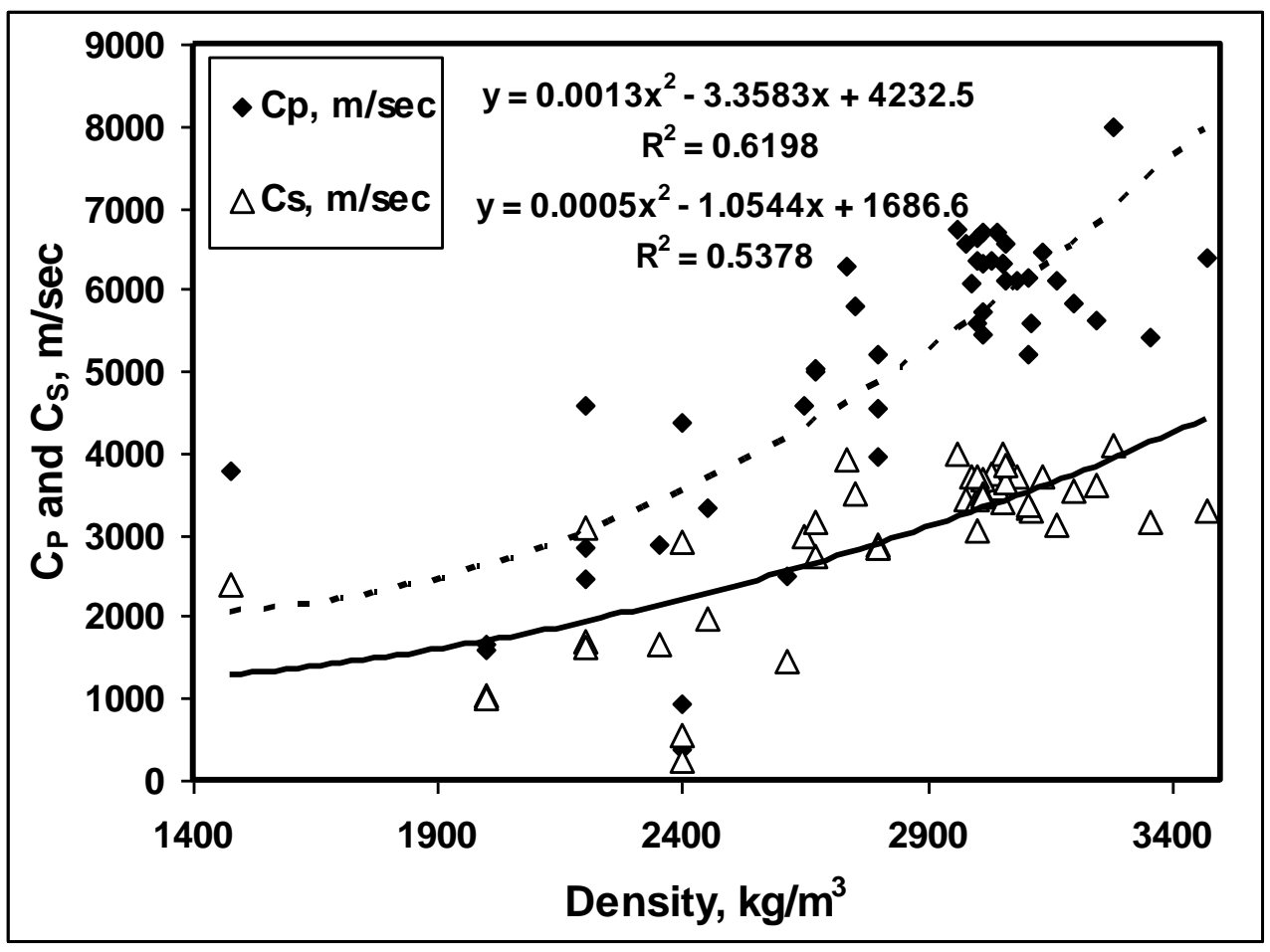

Fig. 1: Relations between $C_{P}$ (dashed line), $C_{S}$ (solid line), and density.

To clarify the differences between $E$ and $G$ magnitudes based on the assumptions of 1-D and 3-D wave propagation, we have plotted E-Increase\% and GIncrease\% versus $\mathrm{C}_{\mathrm{S}} / \mathrm{C}_{\mathrm{P}}$, $v$ and $v$-factor in Fig.4. The figure provides us with very useful information. Firstly, the correlation factors for the six relations are almost equal to one. Secondly, the increase \% for $\mathrm{E}$ and $\mathrm{G}$ is almost the same (data points coincide). Thirdly, the increase in $\mathrm{E}$ and $\mathrm{G}$ magnitudes due to the assumption of 1-D wave propagation can go up to more than $45 \%$. In fact, most of the rock population lies in this range. This is a warning that we should not rely on the old saying that the difference between 1-D and 3-D calculations is not significant and it may be within 5\% $[1,5]$. The figure shows that the difference bypasses $5 \%$ if $\mathrm{C}_{\mathrm{S}} / \mathrm{C}_{\mathrm{P}}$ is less than 0.65 , or $v$ is greater than 0.15 , or $v$-factor is less than 0.96 . The difference increases with increasing $v$ and decreases with increasing $\mathrm{C}_{\mathrm{S}} / \mathrm{C}_{\mathrm{P}}$ ratio and $v$-factor. The figure can be used to check if the difference between 1-D and 3-D calculations exceeds 5\% or not. Indeed, the calculations based on 3-D assumption are better when it comes to field applications. Also, the higher calculated elastic constants will produce higher stress magnitudes. As the 3-D calculations are better for field applications, we have plotted $E_{3-D}$ and $G_{3-D}$ versus density, $C_{P}$ and $C_{S}$ in Fig. 5. Density, $C_{P}$ and $C_{S}$ are measured quantities and constitute the input on which the whole E, G, strain, and stress calculations are based. If the engineering project is at the early stage of feasibility study and measurement facilities are not available or the monitory funds are not enough at that stage, Fig. 5 can be used to estimate $\mathrm{E}$ and $\mathrm{G}$ even by just knowing the density. Fortunately, the correlation coefficients are excellent ranging from 0.83 to 0.99 . 


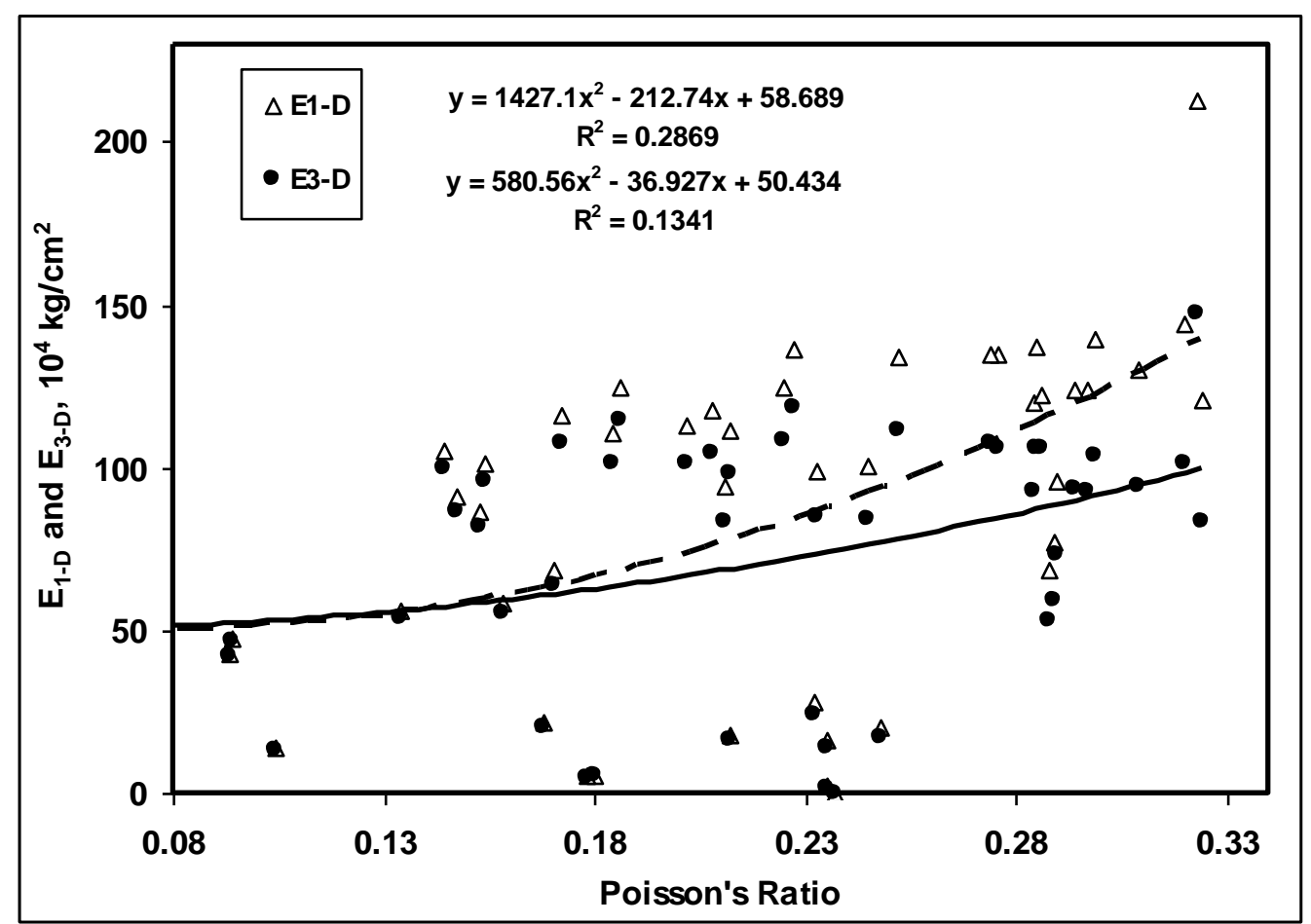

Fig. 2: Relations between $\mathrm{E}_{1-\mathrm{D}}$ (dashed line), $\mathrm{E}_{3-\mathrm{D}}$ (solid line), and $\mathrm{v}$.

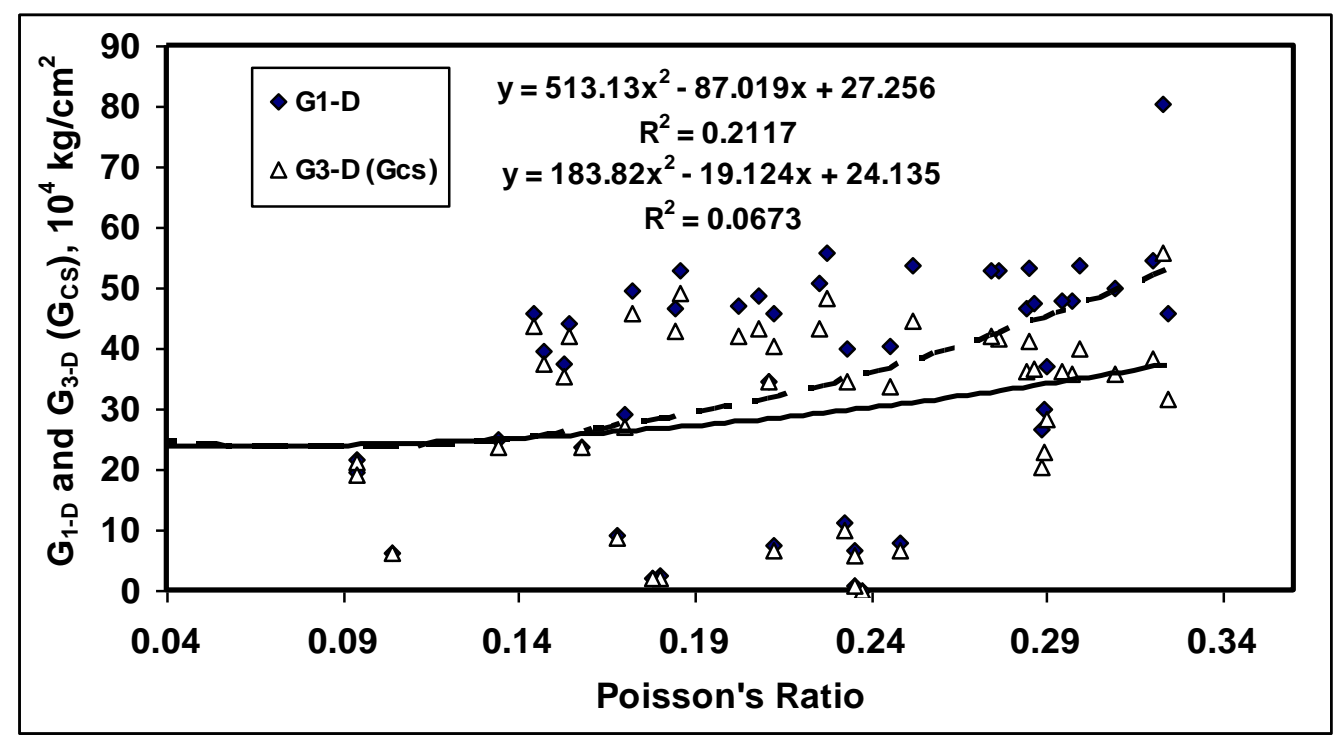

Fig. 3: Relations between $G_{1-D}$ (dashed line), $G_{3-D}$ (solid line), and $v$. 

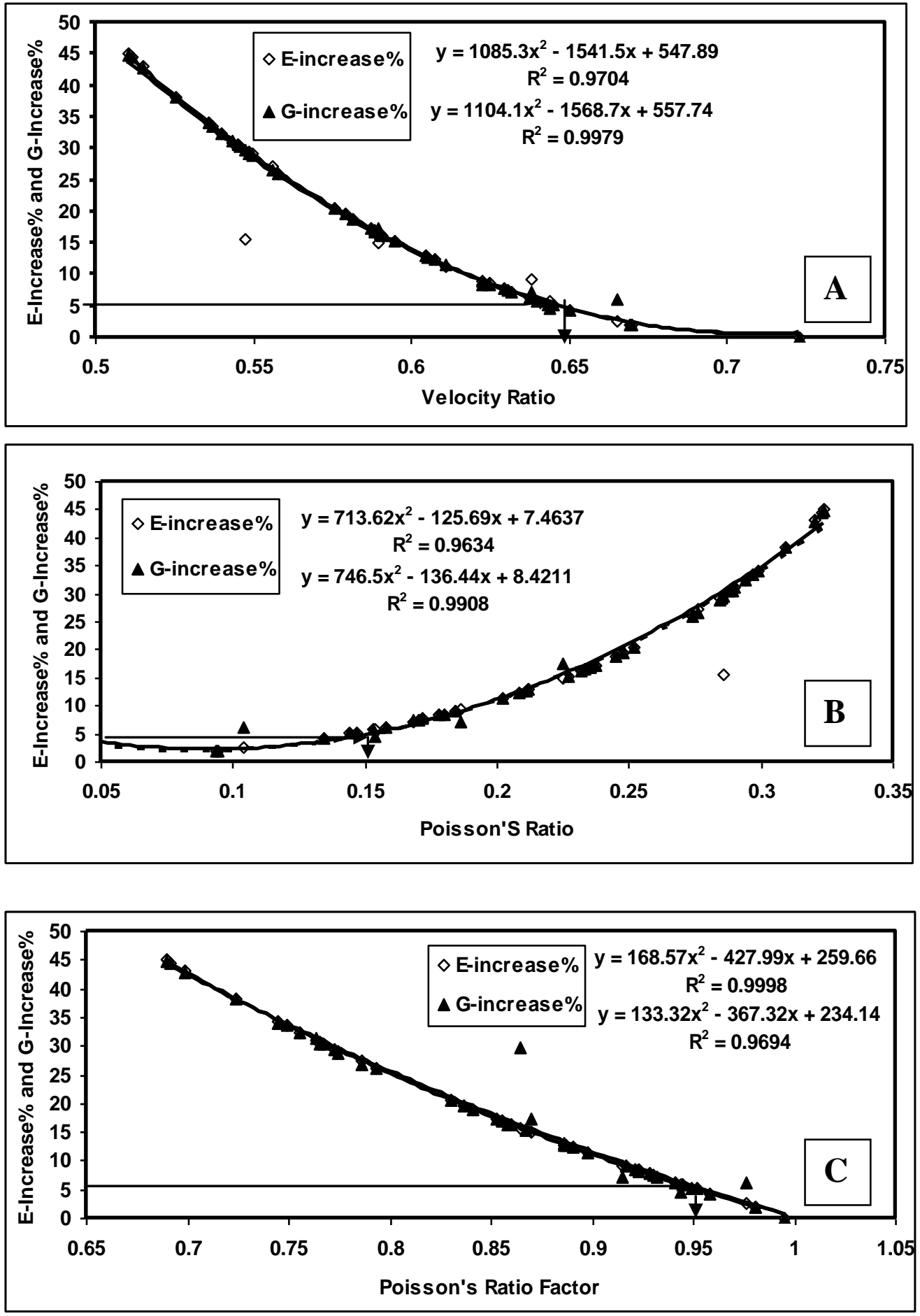

Fig. 4: Relations between E-Increase \& $G$-Increase, $C_{S} / C_{P}$ ratio $(A)$, $v(B)$, and $v$-factor $(C)$. 

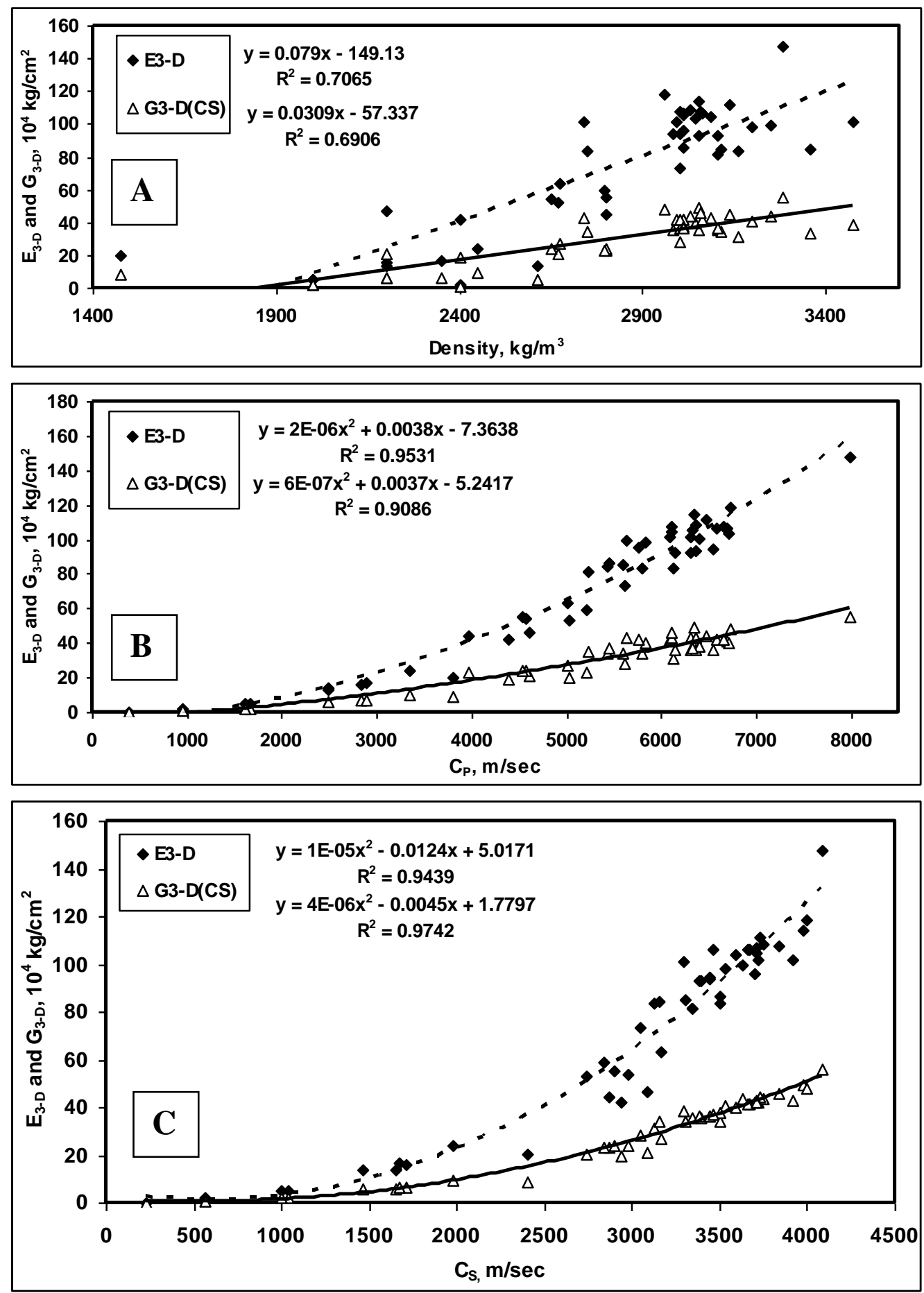

Fig. 5: Relations between $E_{\text {3-D }}$ (dashed line) $\& G_{3-D}$ (solid line); density (A), $\mathrm{C}_{\mathrm{P}}(\mathrm{B})$ and $\mathrm{C}_{\mathrm{S}}(\mathrm{C})$. 
Having illustrated the impact of the assumption of 1-D and 3-D wave propagation on the magnitudes of $\mathrm{E}$ and $\mathrm{G}$, it is time to look at stress calculations. Equation (18), as it is, is providing shear stresses based on 3-D wave propagation. However, using equation (10) for $\mathrm{G}$-calculations will produce either $\mathrm{G}_{1-\mathrm{D}}$ (by plugging $\left.E_{1-D}\right)$ or $G_{3-D}$ (by plugging $E_{3-D}$ ). Hence, one should be aware of that. Considering normal stresses calculated from equation (14), it is based on the assumption of 1-D wave propagation. That is because it is derived from in equation (1), an expression for bar velocity. Accordingly, normal stresses have to be corrected using Fig. 4 if 3-D magnitudes are required. A more appropriate solution to have peace of mind is attained by modifying equation (14) to directly estimate normal stresses using 3-D wave propagation assumption. This can be done by multiplying equation (14) by the $v$-factor to be in the form:

$$
\sigma=\rho \mathrm{C}_{\mathrm{p}} \stackrel{\circ}{\mathrm{p}}_{\mathrm{p}} \mathrm{x}[(1+v)(1-2 v) /[(1-v)]
$$

In other words, we used equation (4) and equation (13) to derive equation (22).

\section{CONCLUSIONS AND RECOMMENDATIONS}

The paper has illustrated the effect of procedure of calculation and the assumptions of 1-D and 3-D wave propagation on the calculated magnitudes of dynamic E, G and stresses. Also, statistical interrelations between rock density, seismic velocity, velocity ratio, Poisson's ratio, and dynamic elastic constants have been derived. From the results of the performed comparisons, calculations, and analyses some conclusions and recommendations have been drawn:

1- Magnitudes of dynamic $\mathrm{E}$ and $\mathrm{G}$ are higher when calculated using 1-D wave propagation assumption than when they are calculated on the 3-D wave propagation basis.

2- The difference between 1-D and 3-D calculations is the same for both $\mathrm{E}$ and $\mathrm{G}$.

3- The difference increases with increasing Poisson's ratio, with decreasing $C_{s} / C_{p}$ ratio and decreasing $v$-factor of the rock material.

4- The difference exceeds $5 \%$ for Poisson's ratio of magnitudes higher than 0.15 , for $\mathrm{C}_{\mathrm{s}} / \mathrm{C}_{\mathrm{p}}$ ratio less than 0.65 , and for $\mathrm{v}$-factor less than 0.96 . The difference can be more than $45 \%$.

5- Dowding' expression for calculating normal stresses has been modified to get 3-D magnitudes by multiplying it by the $v$-factor.

6- Good statistical relations have been obtained between factors affecting estimation of dynamic $\mathrm{E}$ and $\mathrm{G}$ and could be used for their estimation. These include:

i- Relations between $\mathrm{C}_{\mathrm{p}}$ and density; $\mathrm{C}_{\mathrm{s}}$ and density $(\mathrm{R}=0.78$ and 0.73 respectively).

ii- Relations between E-increase $\%$ and $\mathrm{G}$-increase $\%$ versus $\mathrm{C}_{\mathrm{s}} / \mathrm{C}_{\mathrm{p}}$ ratio, vratio, and $v$-factor ( $\mathrm{R}$ for the six relations is almost one).

iii- Relations between $E_{3-D}$ and $G_{3-D}$ versus density, $C_{p}$ and $C_{s}(R$ ranges from 0.83 to 0.99 ).

7- High determined $\mathrm{E}_{1-\mathrm{D}}$ and $\mathrm{G}_{1-\mathrm{D}}$ magnitudes will cause higher estimated stresses than those estimated from $\mathrm{E}_{3-\mathrm{D}}$ and $\mathrm{G}_{3-\mathrm{D}}$. When considering the safe limit of 
blasting vibrations damage criteria, stresses estimated using $\mathrm{E}_{1-\mathrm{D}}$ and $\mathrm{G}_{1-\mathrm{D}}$ will be more conservative.

\section{REFERENCES}

1. Dowding, Charles, "Ground vibration monitoring and control", Prentice Hall, USA, 297 p., (1985).

2. Siskind, D. E., Stagg, M. S., Kopp, J. W., and Dowding, C. H., "Structure response and damage produced by ground vibration from surface Mine blasting", RI 8507, USBM, 74 p., (1980).

3. Abdel-Rasoul, E. I., "Measurement and analysis of the effect of ground vibrations induced by blasting at the limestone quarries of the Egyptian Cement Company", Int. Conf. for Environmental Hazard Mitigation, Center of Environmental Hazard Mitigation, Cairo University, Cairo, Egypt, 15 p., (2000).

4. Burgher, K. E., "P-wave and S-wave velocity measurement for stress-strain analysis", 15th Conf. on Expl. and Blasting Tech., SEE, Ohio, USA, pp. 87-96, (1979).

5. Coates, D. F., "Rock mechanics principles", Monograph 874, CANMET Energy, Mines, and Resources Canada, Ottawa, Canada, Ch. 8, (1981).

6. Tealeb, A. A.; Sobaih, M. E.; Mohamed, A. A., and Abdel-Rahman, K., "Stress level estimation for the ground beneath the 15th of May City buildings, Helwan, Cairo, Egypt", Int. Conf. for Environmental Hazard Mitigation, Center of Environmental Hazard Mitigation, Cairo University, Cairo, Egypt, 29 p., September 9-12, (2000).

7. Elseman I. Abdel-Rasoul and Awad A. Omran, "Estimation of stress and strain levels induced by blasting vibrations using measured particle and propagation velocities at Bani Khalid quarry”, J. of Eng. Sciences, Assiut University, Vol. 35, No. 4, pp. 1009-1021, (2007).

8. Reynolds, J. M., "An introduction to applied and environmental geophysics", John Wiley \& Sons, Chichester, England, 796p., (1997).

9. Sheriff, R. E. and Geldart, L. P., "Exploration seismology, Vol. 1: History, theory and data acquisition", Cambridge University Press, Cambridge, 253 p., (1982).

10. Dobrin, M. B., "Introduction to geophysical prospecting", 3rd Ed., McGrawHill International Book Co., 630 p., (1976).

11. Lama, R. D. and Vutukuri, V. S., "Handbook on mechanical properties of rocksTesting techniques and results", Vol. II, TRANS TECH PUPLICATIONS, Clausthal, Germany, 481 p., (1978).

12. Rzhevsky, V. and Novik, G., "The physics of rocks", MIR PUBLISHERS, Moscow, 319 p., (1971).

13. Atlas Powder Company, "Explosives and rock blasting", Field Tech. Operations", Atlas Powder Co., Dallas, Texas, USA, pp.321-411, (1987).

14. Kabongo, K. K., "Blasting induced damage in coal", Proc. of the 21 st Conf. on Exp. and Blasting Tech., ISEE, Ohio, pp. 203-213, (1995). 


\section{"دراسة بعض العوامل المؤثرة على تعيين ثوابت المرونة الديناميكية للصخور"}

معرفة الخواص الميكانيكية وخواص المرونة للصخور تعتبر أساسية في أي بحث ميكانيكا صخور متصل بالمناجم، الأنفاق، الحفر ، التفجير، القطع، أو الطحن. وتقدير مستوى الاجهادات والانفعالات

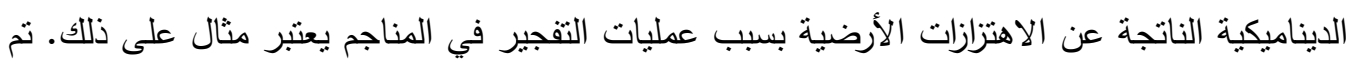

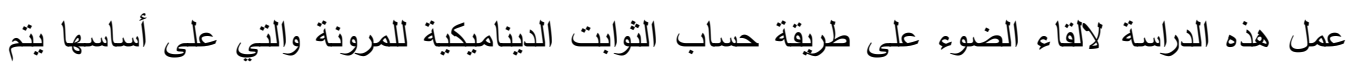

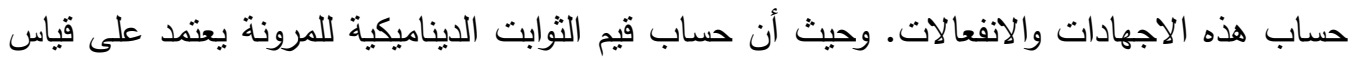

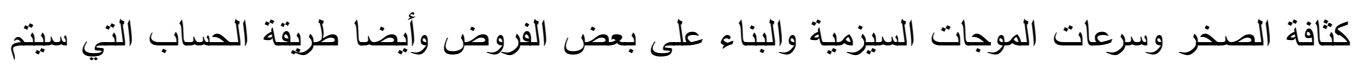
انباعها، فان هذه الدراسة تبحث تأثير فرض انتشار الموجة الأحادي والثلاثي الأبعاد على القيم المحسوبة الثباء لثوابت المرونة وكذلك تبحث الدراسة عن وجود علاقات بينية بين كثافة الصخر والسرعات السيزمية

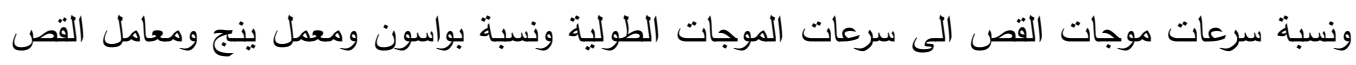
ومعامل نسبة بواسون وأيضا طريقة الحساب.

كثفت الدراسة عن نأثيرواضح لفرض انتشار الموجة الأحادى البعد على زيادة قيم الثوابت الديناميكية

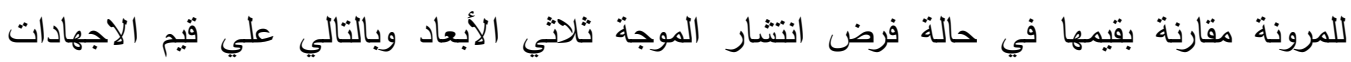

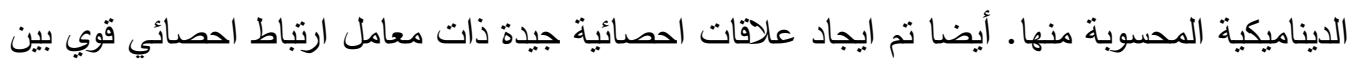

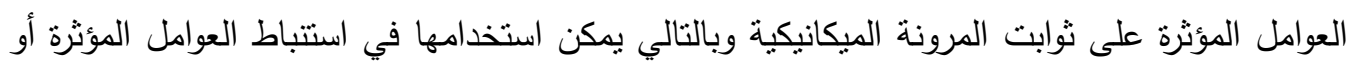

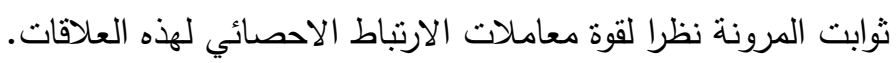

